\title{
TECHNOLÓGIAI PARAMÉTEREK HATÁSA DIGITAL LIGHT PROCESSING 3D NYOMTATÁSI ELJÁRÁSNÁL
}

\section{EFFECTS OF TECHNOLOGICAL PARAMETERS ON DIGITAL LIGHT PROCESSING 3D PRINTING}

\author{
Kun Krisztián ${ }^{1 *}$ \\ 1 Jármütechnológia Tanszék, GAMF Müszaki és Informatikai Kar, Neumann János Egyetem, Magyarország \\ https://doi.org/10.47833/2020.2.ENG.006
}

\section{Kulcsszavak: \\ Fotopolimerizáció \\ DLP eljárás \\ SLA eljárás \\ UV polimerizáció \\ Technológiai paraméterek \\ Additív gyártás}

\section{Keywords:}

Photopolymerization

DLP technology

SLA technology

UV curing

Technological parameters

Additive manufacturing

\section{Cikktörténet:}

Beérkezett 2020. június 10.

Átdolgozva 2020. június 20.

Elfogadva 2020. július 1.

\begin{abstract}
Összefoglalás
A 3D nyomtatási technológiák fejlődési irányát meghatározó tényezők közül kiemelt szerepet kap a produktivitás, a pontosság és a felületminőség. Az elmúlt években a szabadalmi oltalmak lejártával jelentősen elöretört a Digital Light Processing (DLP) eljárás, amely egy új dimenziót nyit az otthoni- és a kisebb vállalatok felhasználóik előtt. Az elterjedtnek tekinthető FDM (Fused Deposition Modeling) eljárással szemben részletgazdagabb, pontosabb és homogénebb felületü additív gyártást kínál. Az eltérő müködési elvböl adódóan a technológiai paraméterek befolyása kevésbé ismert. A cikk célja az eljárás elméleti hátteréből származó, illetve kísérleti úton létrehozott technológiai paraméterek elemzése, azok hatásának vizsgálata a prototípustermékeken.
\end{abstract}

\begin{tabular}{l} 
Abstract \\
Productivity, accuracy and surface quality are among the factors \\
determining the direction of the development of $3 D$ printing \\
technologies. In recent years, with the expiration of patent \\
protections, the Digital Light Processing (DLP) technology has \\
significantly widespread, opening a new dimension to home and \\
small-size enterprises users. Compared to the widely used FDM \\
(Fused Deposition Modeling) technology, it offers more detailed, \\
accurate and more homogeneous surfaced prototypes. Due to \\
the different operating principle, the effects of technological \\
parameters is less known. The aim of the article is to analyze the \\
technological parameters derived from the theoretical \\
background and the experimental results. \\
\hline
\end{tabular}

\section{Bevezetés}

A cikk témáját adó 3D nyomtatási eljárás alapanyaga nem szilárd halmazállapotból (huzalból) kerül megömlesztésre, mint a közismertebb FDM (Fused Deposition Modeling) 3D extrudálás esetén [4]. Alapanyagként UV fényre térhálósodó gyantákat, úgynevezett fotopolimereket alkalmazunk, melyeket folyékony halmazállapotban használunk fel.

\footnotetext{
* Kapcsolattartó szerző. Tel.: +36 76516387

E-mail cím: kun.krisztian@gamf.uni-neumann.hu
} 


\subsection{Fotopolimerek}

Olyan fény által aktivált gyanták, amelyek UV fény hatására szerkezetileg is megváltoztatják tulajdonságaikat: Az anyag megszilárdulása keresztkötés eredményeként történik (1. ábra).

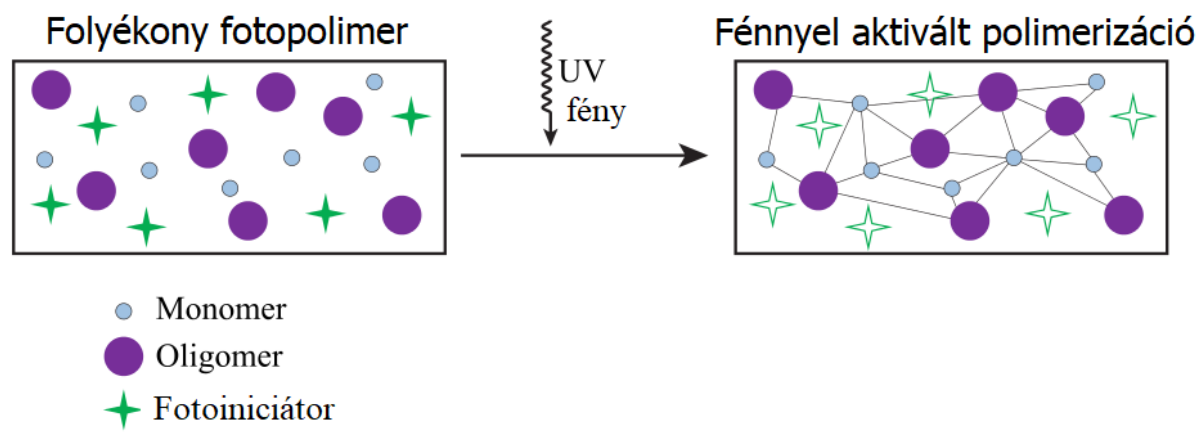

1. ábra. A monomerek, oligomerek és fotoiniciátorok keveréke UV fény hatására szilárd anyaggá alakul. [1]

Legnagyobb részarányban a térhálósodó monomer alkotja. Az aktív, a sugárzásra érzékeny alkotórészt fotoiniciátornak nevezzük. A fotoiniciátor az elnyelt sugárzás hatására szabad gyököt képez, ami elindítja a polimerizációt. Az oligomerek alatt olyan molekulákat értünk, melyek korlátozott számú monomer egységből épülnek fel. Ezek lehetővé teszik, hogy a polimerizáció során ne csak hosszú láncmolekula keletkezzen, hanem elágazásokkal, a tér minden irányában nőjön (térhálósodás). E folyamatot fotopolimerizációnak hívjuk, amelyet az additív gyártásban különböző eljárások hasznosítanak.

\subsection{Az SLA (Stereolithography) 3D nyomtatási eljárás}

1970-ben kezdték kutatni, majd Chuck Hull, a 3D Systems műszaki igazgatója 1984-ben kidolgozta a fotopolimerekkel, rétegről rétegre építkező additív eljárást, amit 1986-ban szabadalmaztatott. Kutatása megteremtette a mai fotopolimeres 3D nyomtatók alapjait.

Az SLA eljárás lényege, hogy CAD rendszerben alkotott, térbeli modelleket egy arra alkalmas szoftverrel vízszintes rétegekre szeletelünk, majd a megfelelő berendezéssel, fotopolimer alapanyagból előállítjuk: Az első keresztmetszet UV fény hatására a tárgyasztalra köt. A fény pozícionálása, a terület pásztázása vezérelt lencsékkel történik. A megszilárdulás után az asztal egy rétegvastagságnyit $(100-25 \mu \mathrm{m})$ süllyed, majd a következő keresztmetszet megvilágítása jön. A folyamat így folytatódik, míg az épülő rétegek egy egészet alkotnak. (2. ábra)

A fotopolimer alapanyagot felhasználó technológiákra jellemző, hogy az elkészült darabokat izopropil-alkohollal tisztítani, majd UV fény alatt utókezelni kell a végleges szilárdság érdekében.

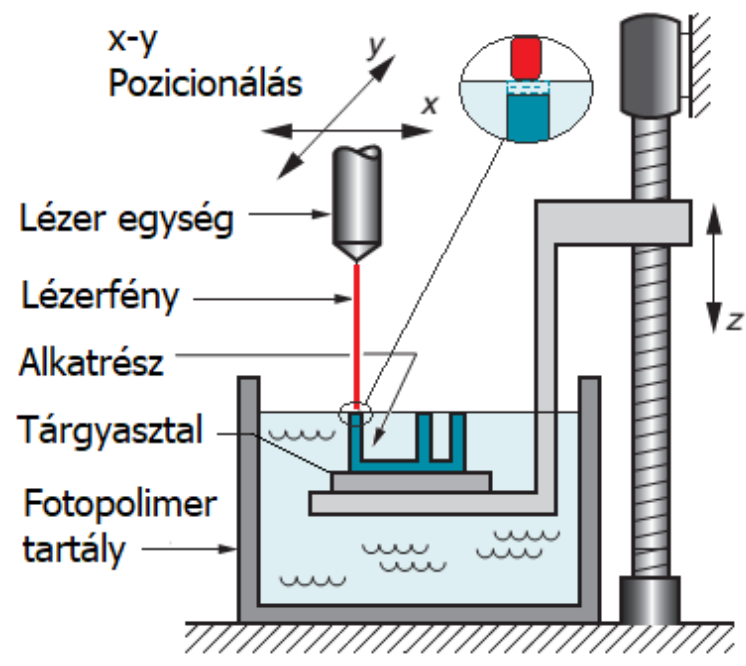

2. ábra. Az SLS eljárás elvi vázlata [2] 


\subsection{A Direct Light Processing (DLP) eljárás}

Elmélete az SLA-n alapul, annak fejlödési eredményeként, mégis önáló eljárásként csoportosítják, mivel az egymásra épülö keresztmetszetek képzésének folyamata eltérő (3. ábra). A modellképzés alábbi lépésekböl áll:

1. A LED UV fényforrás tükrök segítségével egy LCD kijelzöre irányul.

2. Nagy felbontású kijelző a $3 D$ modell alapján generált keresztmetszet projektál programozott időtartamig. Gyakorlatilag a megfelelö keresztmetszeten átengedi az alulról betörő UV fényt. Ezt exponálási szakasznak nevezzük.

3. A kijelző felett a fotopolimer tálcában található, amelynek alja (a kijelzővel érintkező része) vékony, (kb. $0.1-0.2 \mathrm{~mm}$ ) legalább 95\%-ban fényáteresztő (átlátszó) fólia.

Ebbe a folyékony gyantával teli tálcába süllyed bele a tárgyasztal, melynek felületén a kijelző által projektált kép megszilárdul.

4. Az exponált keresztmetszet kötését követően az asztal felemelkedik a tálcából, hogy a megszilárdult anyag helyére visszaáramoljon a folyékony fotopolimer.

\section{Off Time (kiemelés) szakasz}

5. A folyamat folytatásaként a tárgyasztal visszasüllyed a tálcába, majd a következő réteg exponálása következik.

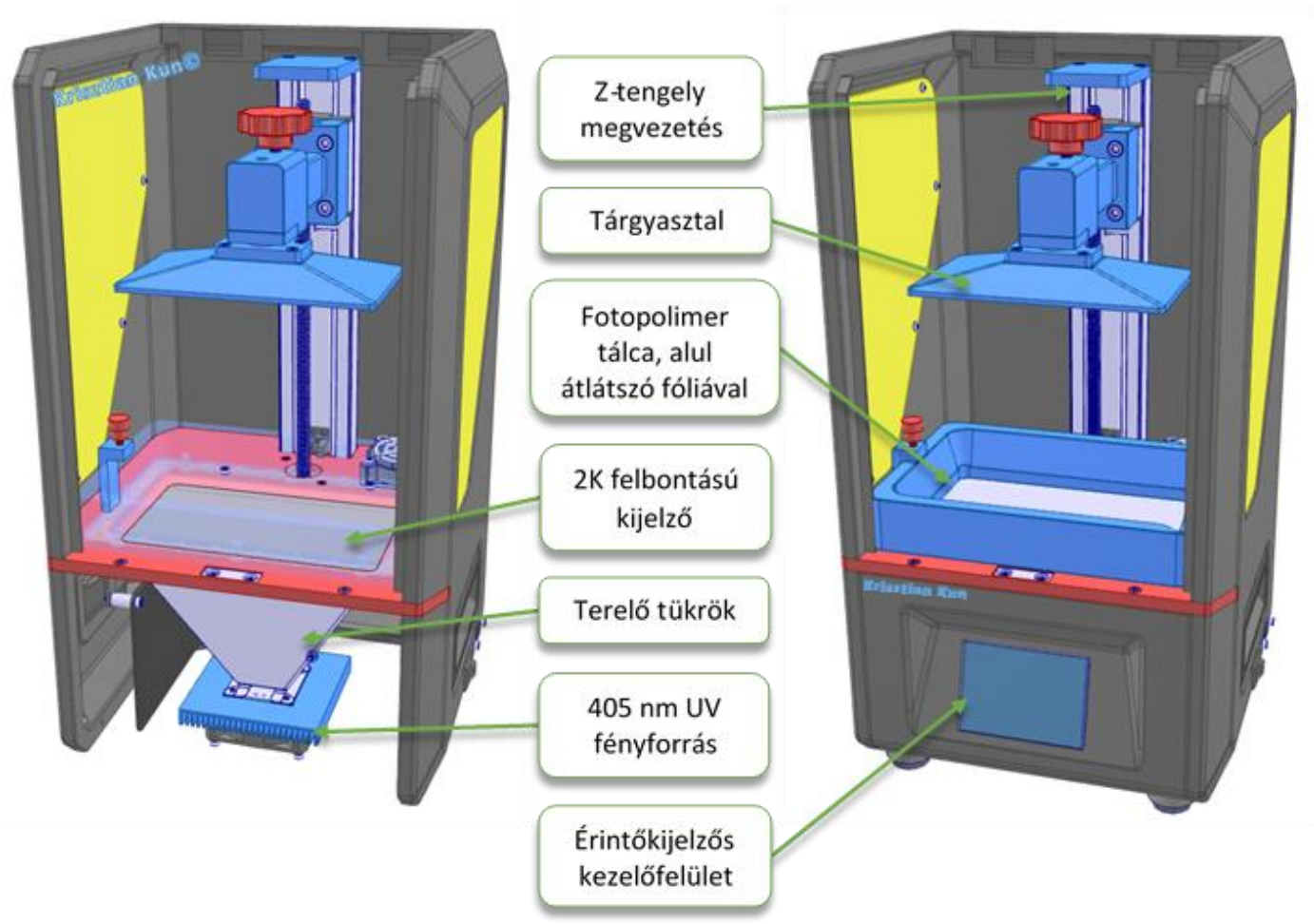

3. ábra. Anycubic Photon típusú, DLP elven müködő 3D nyomtató felépítése

Előny: A DLP eljárás minden eltérő elven müködő technikával szemben rendelkezik egy hatalmas sebességbeli előnnyel: A keresztmetszetek nem pásztázva (pl. SLA, FDM, LOM stb.) készülnek, hanem az egész vázlat egyszerre kerül megvilágításra, szilárdításra, így gyakorlatilag egy alkatrészből a kijelzőre (és a tárgyasztalra) elférő maximális darabszám azonos idő alatt készül el, mintha egyetlen darabot nyomtatnánk. A nyomtatási időt a nyomtatott alkatrész magassága döntően befolyásolja (mivel akár $25 \mu \mathrm{m}$ rétegvastagság is alkalmazható), de annak darabszáma nem. Némileg lassít az eljáráson exponálási szakaszt követő Off-time szakasz. 
Hátrány: A DLP elven müködő 3D nyomtatók nagyfelbontású kijelzői a voxelizáció módszerével építkeznek: Ha kétdimenziós képeknek mélységük lesz „voxelekké” válnak. A voxel egy 3D kép legkisebb megkülönböztethető egysége, amely X-Y-Z tengelyek mentén kiterjedéssel bír. A négyzet keresztmetszetű pixelek méretei $(X-Y)$ tehát meghatározzák a DLP nyomtatóval készült termékek felbontását is. Ez az SLA technikával szemben hátrányként jelentkezik (4. ábra), amely csökkentése érdekében különböző élsimítási (Anti-aliasing) eljárásokat alkalmaznak.

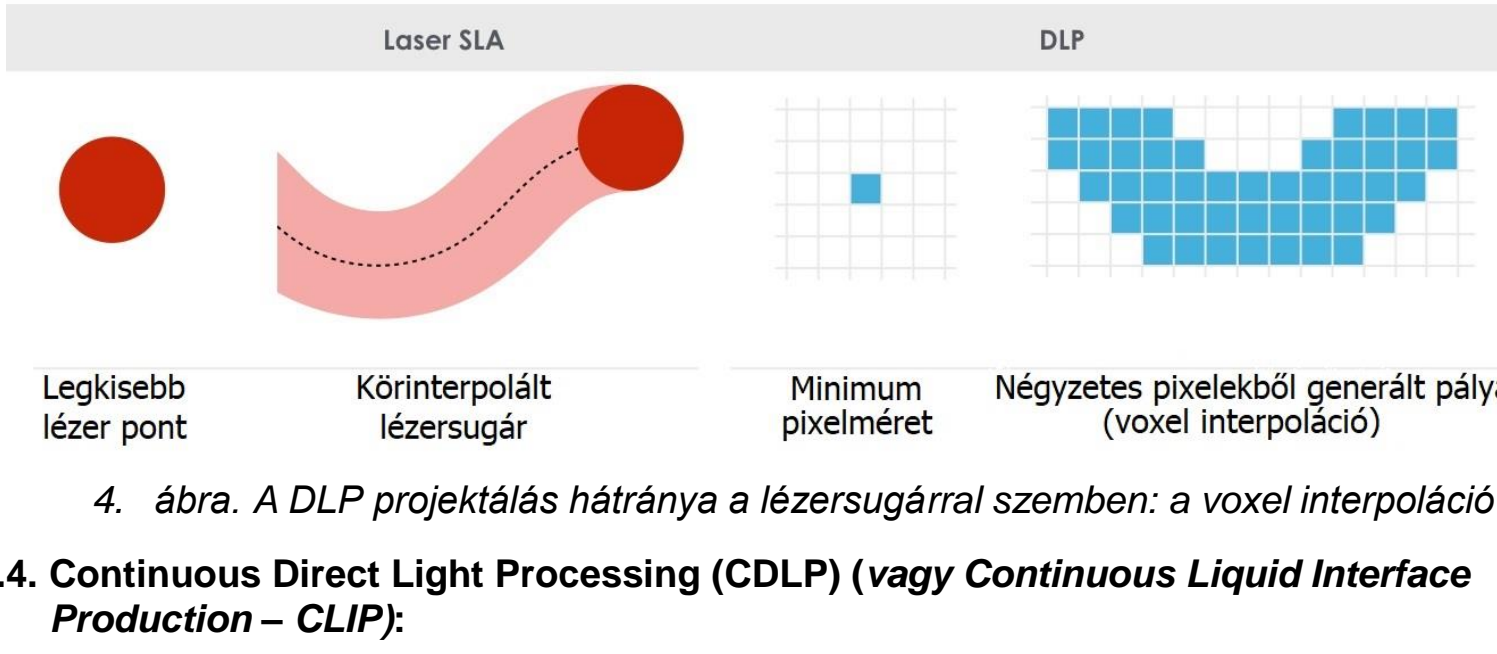

Az eljárás gyakorlatilag egy DLP módszer, Off time szakasz nélkül: technológiai paraméterektől függően akár 25-100-szor gyorsabb, mint az SLA eljárás. A módszer azon alapszik, hogy a fotopolimerek jelentős részénél az oxigén gátolja a térhálósodást.

Az UV fény, a DLP eljáráshoz hasonlóan gondoskodik a modell alapját képező folyékony gyanta megszilárdításáról, míg az oxigén egy 10 $\mu \mathrm{m}$ vastag, szabályozható, reakciómentes zónát (dead zone) képez a tálca alján, amely megakadályozza, hogy a mügyanta a tálca aljához szilárduljon és lehetővé teszi, hogy a tárgyasztal folyamatosan emelkedve mozogjon (5. ábra).

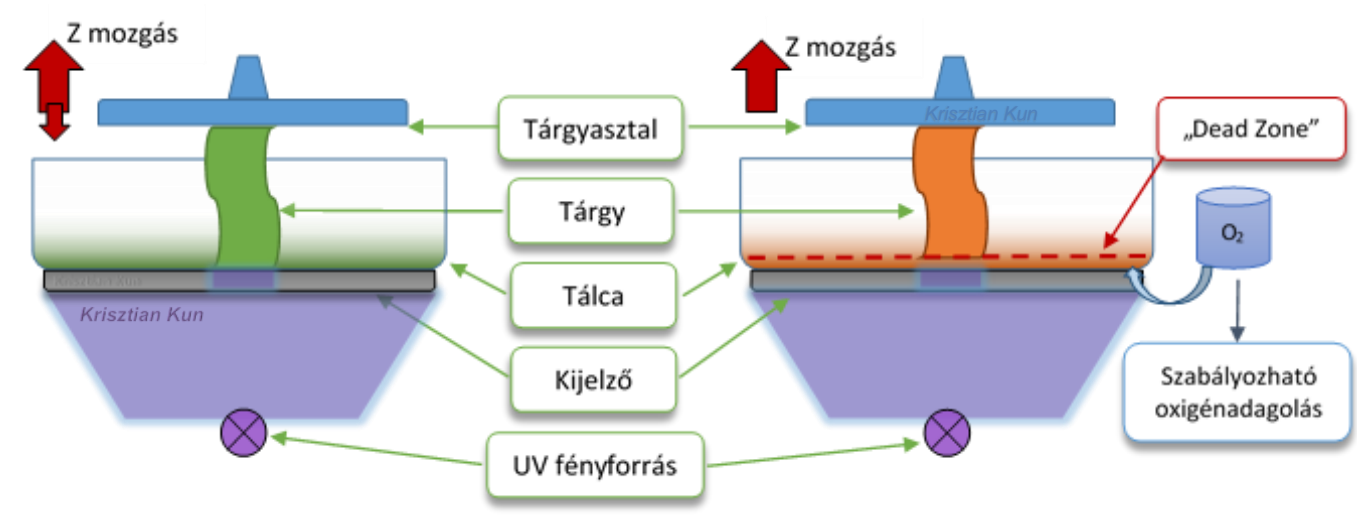

5. ábra. $A D L P$ (balra) és CDLP technológiák összehasonlítása elvi vázlaton

\section{Nyomtatási paraméterek vizsgálata DLP 3D nyomtatásnál}

A kísérlet egy Anycubic Photon DLP nyomtató segítségével történt. A berendezéshez alkalmazott szoftver szeletelésre (Slicer), azaz a rétegalkotásra STL fájlformátumot használ. $A$ szoftverben több lehetséges technológia paraméter változtatható:

- Rétegvastagság - Layer thickness [mm]: 0.05 mm

- Normál expozíciós idő - Normal exposure time [s]: 1. változó - NET

- Kiemelés várakozás - Off time [s] $1 \mathrm{~s}$

- Alsó rétegek expozíciós ideje - Bottom exposure time [s] 2. változó - BET

- Alsó rétegek száma - Bottom layers 8 db 
A kísérleti nyomtatás alapanyaga a berendezéshez ajánlott és a gyártó által forgalmazott fotopolimer gyanta, amely 405nm hullámhosszú UV fény hatására térhálósodik. Az adattáblája a felsorolt technológiai paraméterek közül kettőt emel ki, és tesz ajánlást beállításukra: az alsó rétegek expozíciós idejét, valamint a normál expozíciós időt. Annak érdekében, hogy a tárgyasztalon megtörténjen a kötés az első rétegek (melyek száma külön beállítható) tovább kerülnek megvilágításra (exponálásra), majd egy rövidebb időtartamig (normál expozíciós idő) az őket követő többi réteg. Ezek hatása tehát kiemelt jelentőségü.

A kísérletervezés Taguchi-módszer alkalmazásával történt, amely Minitab17 szoftver segítségével készült. A módszer segít megtalálni a kísérleti eredményre legnagyobb hatással bíró faktorokat, valamint azok lehetséges kombinációit. Segít megállapítani az optimális eredményt hozó faktorkombinációt. A kísérlettervben szereplő nyomtatási faktorok az alsó rétegek expozíciós ideje (BET), valamint a normál expozíciós idő (NET) volt. A generált kísérletterv az 1. táblázatban látható.

\section{Táblázat. Taguchi kísérletterv}

\begin{tabular}{|c|c|c|c|}
\hline Kísérlet sorszáma & $\mathrm{NET}[\mathrm{s}]$ & $\mathrm{BET}[\mathrm{s}]$ & Nyomtatás időtartama \\
\hline 1. & 5 & 20 & 50 perc \\
\hline 2. & 5 & 50 & 54 perc \\
\hline 3. & 5 & 80 & 58 perc \\
\hline 4. & 10 & 20 & 1 óra 29 perc \\
\hline 5. & 10 & 50 & 1 óra 17 perc \\
\hline 6. & 10 & 80 & 1 óra 33 perc \\
\hline 7. & 15 & 20 & 2 óra 8 perc \\
\hline 8. & 15 & 50 & 2 óra 12 perc \\
\hline 9. & 15 & 80 & 2 óra 16 perc \\
\hline
\end{tabular}

\subsection{Próbatest nyomtatás Anycubic Photon DLP 3D nyomtatóval}

A kísérletterv megalkotását ezen keresztül pedig a vizsgált paraméterek kiválasztását a nyomtatott próbatest tervezése követte. A próbatesteken geometriai mérésen keresztül került elemzésre a beállított paraméterek hatása. Ennek érdekében a tervezett munkadarabon a 6 . ábrán betűkkel külön megjelölt méretek vizsgálata történt.
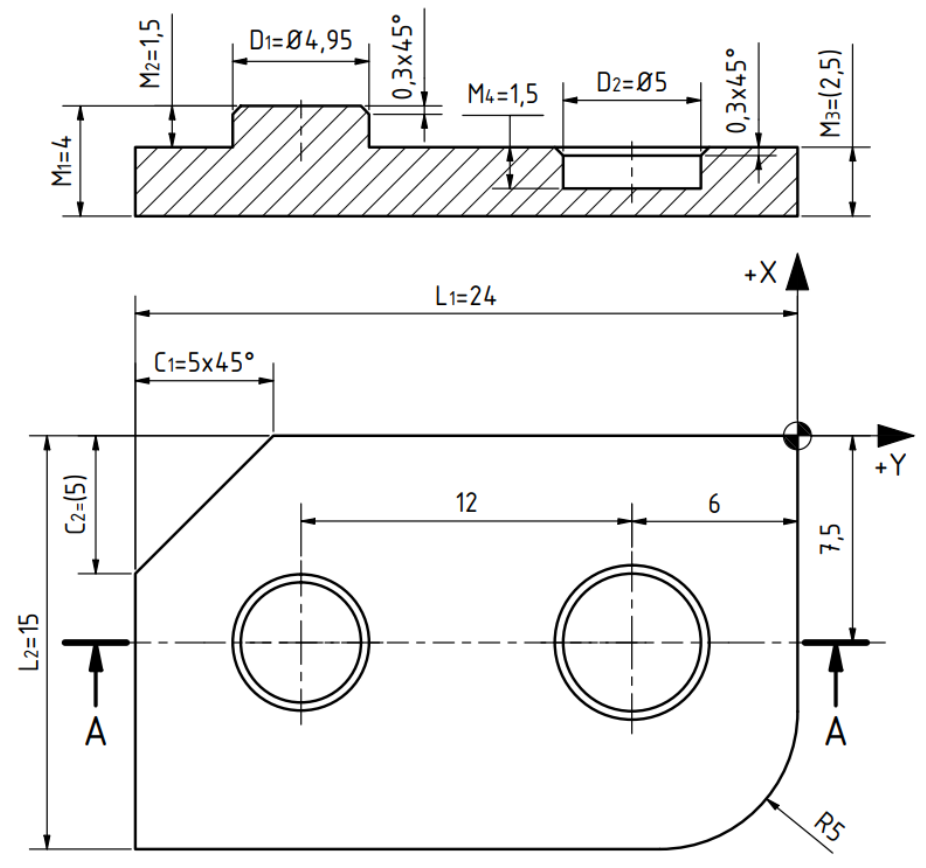

6. ábra. A tervezett próbatest jelölt geometriai méretekkel 
A próbatest öt különböző állásban került kinyomtatásra, ezzel vizsgálható a „voxel-hatás”, valamint a technológiai paraméterek hatása eltérő geometriai elemekre, alaksajátosságokra.

A kinyomtatott darabok térben elhelyezett pozícióját szemlélteti a 7 . ábra. A nyomtatás elkészültével a kísérleti alkatrészek ultrahangos tisztítóban, izopropil-alkohollal tisztítást, majd 10 percig, 405nm hullámhosszú UV kamrában utókeményítésként fénykezelést kaptak.

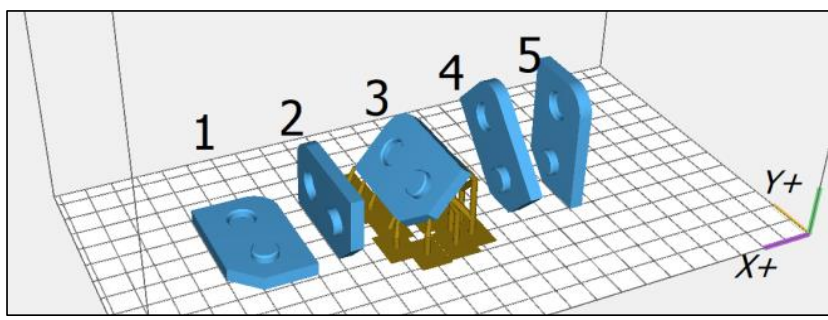

7. ábra. A próbatest öt különböző pozícióban került nyomtatásra.

\section{Eredmények kiértékelése}

Az próbatestek kiértékelése kalibrált, hitelesített digitális tolómérő, illetve digitális magasságmérő segítségével történt. A hossz- és a magasságméretek mellett a két átmérő $X$, illetve $Y$ tengelyen egyaránt mérésre került az ovalitás ellenőrzése érdekében.

\section{Táblázat. A kísérletterv alapján optimális nyomtatási eredményt hozó paraméterek}

\section{Szintek}

\begin{tabular}{llccccc} 
& Nyomtatási faktorok & 1 & 2 & 3 & \\
\hline $\boldsymbol{A}$ & Normál expozíciós idő (NET) [s] & 5 & $\underline{\mathbf{1 0}}$ & 15 & & \\
$\boldsymbol{B}$ & Alsó rétegek expozíciós ideje (BET) [s] & 20 & $\underline{\mathbf{5 0}}$ & 80 & & \\
$\boldsymbol{C}$ & Pozíció & $\underline{\mathbf{1}}$ & $\mathbf{2}$ & 3 & 4 & 5
\end{tabular}

A 2. táblázat a cikk maximális terjedelme miatt csupán azon eredményeket emeli ki, amelyek a próbadarab legpontosabb gyártását eredményezték. A 45 kinyomtatott próbatest több mint 700 mért felülete objektív képet adott az optimális paraméterek alkalmazásához. Ezek alapján elmondható, hogy az alacsony expozíciós idők bár rövidebb nyomtatást eredményeznek, a darabok tárgyasztalhoz gyengébben kötődnek, ami sikertelen nyomtatást okozhat. Túl hosszú expozíciós idők alkalmazása esetén azonban fenn áll a lehetősége annak, hogy az anyagban fényterjedés következtében a tervezettnél nagyobb méretek készülnek. A 2. táblázatban aláhúzással jelölt optimális beállítással a méretek átlagosan $\pm 0,1 \mathrm{~mm}$ türéshatáron belül készültek el. A többi beálltást tekintve a sikeresen nyomtatott darabok méretei általánosan $\pm 0,3 \mathrm{~mm}$ türéshatárba kerültek.

\section{4. Összegzés}

A nyomtatási paraméterek vizsgálata 9 kísérleti beállítás mellett történt, melyek mindegyike 5 darab próbatestet tartalmazott. A kísérlet eredményei jól szemléltetik, hogy az alapanyag adatlapján ajánlott technológiai paraméterskála egyes kombinációkban jelentős eltérést mutat a késztermék minőségében, sőt akár sikertelen nyomtatást is eredményezhet. A hosszméretek pontossága és a furatok-csapok méretének szórása mellett alakhiba is megfigyelhető. A kísérlet eredménye a próbatest nyomtatásához optimális beállítást szolgáltatott. A makrogeometriai mérések mellett azonban a mikrogeometriai eltérések összehasonlító vizsgálata további kutatást igényel.

\section{Irodalomjegyzék}

[1] James V. Crivello and Elsa Reichmanis - Photopolymer Materials and Processes for Advanced Technologies Chemistry of Materials 201426 (1), 533-548 DOI: 10.1021/cm402262g

[2] John Wiley \& Sons, Inc. M P Groover, Fundamentals of Modern Manufacturing Elöadás: 4/e

[3] Scott Frey - Laser SLA vs DLP 3D Printing Technology March 23, 2017. [Online] Available: https://theorthocosmos.com/laser-sla-vs-dlp-vs-masked-sla-3d-printing-technology-compared/ [10-Nov-2019].

[4] Krisztian Kun - Reconstruction and Development of a 3D Printer Using FDM Technology, Procedia Engineering Volume 149, 2016, Pages 203-211 [Online] Available: https://doi.org/10.1016/j.proeng.2016.06.657 [10-Nov-2019]. 